\title{
External Debt and Economic Growth in Nigeria: An Implication for Debt Overhang Theory
}

Fagbola Lawrence Olusegun, PhD

Osun State University, Nigeria

Sokunbi Gbenro Matthew

Michael Otedaola College of Primary Education, Nigeria

Aderemi Timothy Ayomitunde

Olabisi Onabanjo University, Nigeria

Adebayo Abiola Georgina

Wageningen University and Research, Netherlands

Doi: 10.19044/elp.v7no2a3 $\quad$ URL:http://dx.doi.org/10.19044/elp.v7no2a3

\begin{abstract}
In the recent times, several agitations have surrounded the huge external debts incurred by the Mohammed Buhari led government in the past four years, and the current approval of $\$ 22.7$ billion external debt by the Nigerian National Assembly has sparked off debates among scholars and policymakers. Against this backdrop this study critically examined the contribution of external debts to economic growth in Nigeria from 1981 to 2018 via the application of Autoregressive Distributed Lag model and Bounds Testing techniques. The significant contributions of this study to the field of research are as follows; past economic growth did not contribute to the present economic growth in Nigeria. In the same vein, external debt caused a significant setback to economic growth in Nigeria during the periods under investigation. Meanwhile, debt servicing and economic growth had a direct relationship in the country. Exchange rate contributed a negative impact on economic growth. Whereas, the foreign reserves had a positive and significant impact on economic growth in Nigeria. Consequently, the emergence of these crucial findings make this study to recommend the following for the policy makers in Nigeria in particular, and other highly indebted countries in Africa that past external debts in Nigeria are inhibitors to economic growth in the country. Therefore, policymakers in Nigeria should explore other means of financing country`s deficit budget rather than external debt.
\end{abstract}

Keywords: External Debt; Debt Service Payment; Exchange Rate; ARDL: Nigeria.

JEL Classification: F3, 31 


\section{Introduction}

In the recent times, debt overhang theory has been a burning issue in a highly indebted country like Nigeria. Debt overhang theory is a phenomenon in a country whereby debt servicing consumes substantial resources in such way that economic growth is stifled in that country. Meanwhile, Nigeria is a country characterized with a low economic growth, low per capita income and inadequate domestic savings, which make it very difficult for the country to meet its developmental goals. In the past few decades, the inability of Nigeria to avoid external debt lies in the over reliance of the country on oil and gas, which its price has been volatile in the global market. At the same time, Nigerian exports are geared towards primary products which lack value addition, as such it could not generate enough foreign exchange earnings to finance imports of capital goods resulting into trade deficit in the country (Siddique, Selvanathan and Selvanathan, 2015).

Historically, it is interesting to note that heavy debt burden in Nigeria could be traced to around late 1970s and early 1980s due to a very sharp dwindling in oil revenues. This burden became aggravated when the Babaginda's regime adopted the IMF's Structural Adjustment Programme (S.A.P) in 1986, which facilitated disbursement of loans by this institution to the Nigerian government. The periods of 1986 to 1993 were connected with huge external debts which could not be traced to any meaningful developmental projects in the country. Explicitly, Nigeria incurred external debt of approximately \$1 billion in 1971, which rose to \$33.5 billion in 1991 . The Nigeria's external debt stock valued at \$29 billion in 1999 when democracy resurfaced. External debt stood at $\$ 28.7$ billion in 2015 when the Mohammed Buhari led administration came on board. However, from 2016 to 2018 , external debt has risen from $\$ 30.6$ billion to $\$ 46.2$ billion. This implies that external debt increased by $37.8 \%$ between 2015 and 2018 in Nigeria (WDI, 2019).

Consequently, there is nothing bad for a country to embark on external debt if such debt will stimulate economic growth and development. But in the case of Nigeria, huge external debt has been a burden in the country in the past few decades due to the lack of optimal utilization, debt management and servicing problem (Adepuju, Salau and Obayelu, 2007; Sanusi, 2003). It is expected that economic growth should accompany the past inflows of external debt in Nigeria. An attempt to empirically establish the above statement has orchestrated divided opinions among the scholars in the recent times. For instance, Udeh, Ugwu and Onwuka (2016) argued that external debt stimulated economic growth in Nigeria only in the short run. While reverse was the case in the long run. Meanwhile, other authors like Ogbonna and Appah (2016), Sulaiman and Azeez (2012) asserted that external debt led to economic growth in the long run. However, Bamidele and Joseph (2013), 
Ogege and Ekpudu (2010) submitted that external debt has been an inhibitor to the Nigerian economic growth.

It could be pinpointed from the above that literature is highly controversial regarding the nexus between external debt and economic growth in Nigeria. Against this backdrop, this study tested the existence or otherwise of the debt overhang theory in Nigeria. Also, the uniqueness of this lies in utilizing latest econometric technique in which the majority of recent studies have undermined.

This work is structured as follows; foundation of this study is laid in the introductory aspect. Meanwhile, section two presents the review of the relevant literature. In the section three, methodology, discussion of results, conclusion and policy implication of this study are consequently presented.

\section{Objective of the Study}

The objective of the study is to examine the nexus between external debt and economic growth in Nigeria from 1981 to 2018

\section{Literature Review}

\section{The Debt Overhang Theory}

The high level of indebtedness of majority of countries in Africa, especially Nigeria in the recent times makes debt overhang theory a subject of interest. External debt and economic growth has been a complex phenomenon in developing economies. Debt overhang theory submits that what makes the pace of investment to decline in an economy is debt overhang. The bone of contention of this theory is that any country that lacks repayment ability of its debt, there is high level of probability in the future that the output of such country will not be able to provide the expected debt servicing. This could serve as a discouraging factor for both local and foreign investors because some of the returns from investing in the domestic economy could be redistributed to the existing foreign creditors through excessive taxes in an attempt by the indebted country to service the debt and repay the principal.

Meanwhile, the wide scope of debt overhang is manifested in such a way that its effects are felt in investment in physical capital and any activity that incurring of costs upfront with aim of future increment in output. It is worth of note that these activities involve the investment in human capital and advancement of technology which are the back bone of economic growth over time. However, the approach of the indebted country in raising resources for servicing of external debt with complementarity of investment of private and public domains largely depends on the way a debt overhang repels private investment. For example, inflation tax or capital levy by the government could discourage private investment. For instance, if a government embarks on inflation tax or in a capital levy, this might serve as a discouraging factor to 
private investment. Consequently, the submission of a debt overhang theory is that additional investment brings about very little returns in indebted country as a result of the need for the country to service its debt. Therefore, servicing a large volume of foreign debt could hinder economic prosperity of a country through the crowding out effect, because high real interest rate could make the borrowed country to worse off and eventually shut-off from foreign credit market. The decline in the available resources of the country will incapacitate the country to finance investment and macroeconomic conditions, this eventually leads to a decrease in investments and fall in output.

\section{Empirical Review}

Over time, nexus between external debt and other macroeconomic variables has been well pronounced in the literature. In a study carried out by Udeh, Ugwu and Onwuka (2016), Ordinary Least Square was used to estimate the relationship between external debt and economic growth in Nigeria from 1980 to 2013. The authors argued that the relationship between external debt and economic growth was direct in the short run, but the reverse was the case in the long run. At the same time, external debt service payment showed an inverse relationship with economic growth in Nigeria. While conducting a study in Debt Trap Countries (DTC) and Non Debt Trap Countries (NDTC) of Asian pacific development countries, Alam and Taib (2013) examined a linkage between external debts, budget deficit, current account deficit and exchange rate depreciation in the above mentioned countries. It was discovered from the study that a positive nexus existed among external debt, budget deficit, current account deficit and exchange rate depreciation. However, there were variations in the level of the significance of the nexus in DTC and NDTC. In another related study focusing on Nigeria, Ogege and Ekpudu (2010) employed Ordinary Least Square to assess how debt burden and economic growth were related in Nigeria. The authors posited that debt stock hindered the Nigerian economic growth.

Meanwhile, in Tanzania between 1990 and 2013, Kasidi and Said (2013) estimated the relationship between external debt and economic growth in that country. It was inferred from the work that the Tanzanian economic growth felt a significant positive impact of the external debt whereas the reverse was the case of debt service payment. In the same vein, how domestic and external debt impacted Pakistan`s economic growth was investigated between 1980 and 2010 was investigated by Atique and Malik (2012) with the application of both Ordinary Least Square and Cointegration techniques. The authors asserted that both domestic and external debts discouraged economic growth in the country. In another study, Ijeoma (2013) adopted a linear regression model to examine how external debt stock, external debt service payment and some selected macroeconomic variables 
were related in Nigeria. It was submitted that debt servicing and gross fixed capital formation had a significant relationship. Economic growth of the country was affected by exchange rate fluctuations, external debt shock, and external debt servicing.

In addition, Sulaiman and Azeez (2012) utilized Co-integration test and Error Correction model to investigate the linkage between external debt and economic growth in Nigeria. The authors enunciated that a long-run equilibrium relationship was found among the variables of interest. Also, the Nigerian economy has immensely benefited from external debt. Similarly, Malik, Hayat, and Hayat (2010) employed regression analysis to evaluate the linkage between external debt and economic growth in Pakistan from 1972 to 2005. The study concluded that external debt had a significant negative impact on economic growth in the country. Ogunmuyiwa (2011) explored Vector Error Correction Method (VECM) to research the contribution of external debt on economic growth in Nigeria between 1970 and 2007. No existence of causal relationship between external debt and economic growth in Nigeria was discovered. In another study, Adesola (2009) used multiple regression analysis to estimate the nexus between external debt service payment and economic growth in Nigeria between 1981 and 2004. It was discovered the gross fixed capital formation and economic growth in Nigeria were stimulated by debt payment to Paris club creditors and Promissory Notes holders. Whereas, debt payment to London club creditors and other creditors proved otherwise on gross fixed capital formation and economic growth in Nigeria.

In conclusion, it could be inferred from the reviewed studies that nexus between external debt and economic growth are ongoing in developing countries, especially Nigeria, and the literature has been highly controversial in the recent times. Hence, the relevance of this work.

\section{Methodology and Estimation}

Secondary data from 1981 to 2018 were utilized in this study. External debt, debt service payment, GDP and foreign reserve were extracted from World Development Indicators. Meanwhile, exchange rate data were collected from the Central Bank of Nigeria statistical bulletin.

\section{Empirical Model}

In accounting for the nexus between external debt and economic growth in Nigeria, the model for the analysis of this study is specified as follows;

Economic Growth $=$ F (External Debt)

Explicitly, equation (1) could be restated as;

$\mathrm{EGt}=\mathrm{F}(\mathrm{ExtDt}, \mathrm{DSPt}, \mathrm{FRt}, \mathrm{Exch})$

Linearizing equation (II) generates equation (III) as follows; 
$\mathrm{EGt}=\beta_{1}+\beta_{2} \mathrm{ExDt}+\beta_{3} \mathrm{DSPt}+\beta_{4} \mathrm{FRt}+\beta_{5} \mathrm{Excht}+\mu_{\mathrm{i}}$

\section{ARDL Model Specification}

Employment of ARDL and Bounds test model in this study is as a result of unit root test performed on variables of interest, which shows that the variables are I(1) and I(0) nature. Meanwhile, Pesaran, Shin and Smith (2001); Pesaran and Pesaran (1997) argued that when the variables of interest are the combination of stationarity and non-stationarity data, ARDL model is the best technique of analysis. Therefore, ARDL model is specified as follows;

$\Delta E G_{t}=\beta_{1}+\sum_{i=1}^{p} \beta_{2} \Delta E G_{t-1}+\sum_{i=0}^{p} \beta_{3} \Delta E x D_{t-1}+\sum_{i=0}^{p} \beta_{4} \Delta D S P_{t-1}+$ $\sum_{i=0}^{p} \beta_{5} \Delta F R_{t-1}+\sum_{i=0}^{p} \beta_{6} \Delta E x c h_{t-1}++\mu \mathrm{i}$

Where;

$\mathrm{EG}=$ this represents economic growth and Real Gross Domestic Product is used to proxy it. ExD is used to capture external debt incurred by the country. DSP is debt service payment. FR represents foreign reserves while Exch is official exchange rate in the country. $\mu=$ Stochastic or error term and $t=1981$ 2018.

The a priori expectations are as follows $\beta_{2} \beta_{3}$ and $\beta_{5}>0, \beta_{4}$ and $\beta_{6}<0$.

\section{Results}

Table 1: Descriptive Statistics of Annual Data Series (1981-2018)

\begin{tabular}{|l|l|l|l|l|l|}
\hline $\begin{array}{l}\text { Descriptive } \\
\text { Statistics }\end{array}$ & EG & ExtD & DSP & FR & Exch \\
\hline Mean & $6.0 \mathrm{E}+148$ & 1212.816 & 285022.6 & 2881686 & 76.59172 \\
\hline Median & $2.31 \mathrm{E}+13$ & 625.1685 & 46353.37 & 92739.20 & 57.37220 \\
\hline Maximum & $2.2 \mathrm{E}+150$ & 4890.270 & 4545934 & $\begin{array}{l}6842211 \\
7\end{array}$ & 253.4923 \\
\hline Minimum & $1.71 \mathrm{E}+12$ & 2.331200 & 1092.300 & 5479.700 & 0.610025 \\
\hline Std. Deviation & $3.6 \mathrm{E}+149$ & 1390.059 & 799339.7 & $\begin{array}{l}1143412 \\
1\end{array}$ & 72.03856 \\
\hline Skewness & 0.747049 & 0.281563 & 0.509493 & 0.449177 & 0.423730 \\
\hline Kurtosis & 3.028574 & 3.412852 & 2.927893 & 3.728601 & 1.985552 \\
\hline Jargue-Bera & 1642.330 & 10.11009 & 778.9783 & 1416.160 & 2.620939 \\
\hline Probability & 0.000000 & 0.006377 & 0.000000 & 0.000000 & 0.269693 \\
\hline Sum & $2.2 \mathrm{E}+150$ & 43661.39 & 1026081 & $1.04 \mathrm{E}+08$ & 2757.302 \\
\hline Sum. Sq. Deviation & $4.6 \mathrm{E}+300$ & 67629204 & $2.24 \mathrm{E}+13$ & $4.58 \mathrm{E}+15$ & 181634.4 \\
\hline Observation & 37 & 37 & 37 & 37 & 37 \\
\hline
\end{tabular}

Source: Authors` Computation (2020) 
The above table shows various descriptive statistics of the variables of interest in this study. For instance, economic growth and exchange rate data have mean values greater than their standard deviations. This implies that economic growth data did not widely deviate from the both sides of mean and moderately dispersed during the periods under investigation. Similarly, considering coefficients of skewness and Kurtosis of economic growth which are 0.747049 and 3.028574 respectively indicate that economic growth data are are positively skewed and agreed with the assumption of symmetrical distribution. But, exchange rate data have a Kurtosis value far from 3, this implies that the data might not agree with a symmetrical distribution assumption. Meanwhile, external debt, debt service payment and foreign reserve have mean values less than their standard deviations. This means that the data were widely deviated from both sides of their mean and dispersed under the periods under study. The data is positively skewed and agreed with the assumption of symmetrical distribution because their values of Kurtosis are around 3.

However, from the above descriptive statistics, it could be inferred that the majority of the data were distributed fairly and as such, the data could be used for econometric analysis.

Table 2: Unit Root Test

\begin{tabular}{|c|c|c|c|c|c|}
\hline \multirow[t]{2}{*}{ Variables } & \multicolumn{4}{|c|}{ ADF Test } & \\
\hline & Level & Probability & $1^{\text {st }}$ Diff & $\begin{array}{l}\text { Probabilit } \\
\mathrm{y}\end{array}$ & $\begin{array}{l}\text { Remar } \\
\mathrm{k}\end{array}$ \\
\hline EG & $-3.632900^{* * *}$ & 0.0000 & & & $\mathrm{I}(0)$ \\
\hline ExtD & -3.632900 & 0.3210 & -3.632900 & 0.0193 & $\mathrm{I}(1)$ \\
\hline DSP & -3.699871 & 0.9986 & -3.711457 & 0.0016 & $\mathrm{I}(1)$ \\
\hline Exch & -3.626784 & 0.9999 & -3.632900 & 0.0130 & $\mathrm{I}(1)$ \\
\hline FR & -3.653730 & 0.9999 & -3.689194 & 0.0021 & $\mathrm{I}(1)$ \\
\hline \multirow[t]{2}{*}{ Variables } & \multicolumn{4}{|c|}{ PP Test } & \\
\hline & Level & Probability & $1^{\text {st }}$ Diff & $\begin{array}{l}\text { Probabilit } \\
\text { y }\end{array}$ & \\
\hline $\mathrm{EC}$ & $-3.632900 * * *$ & 0.0000 & & & $\mathrm{I}(0)$ \\
\hline ExtD & -3.626784 & 0.6668 & -3.632900 & 0.0259 & $\mathrm{I}(1)$ \\
\hline DSP & -3.699871 & 0.9986 & -3.711457 & 0.0006 & $\mathrm{I}(1)$ \\
\hline Exch & -3.626784 & 0.9999 & -3.632900 & 0.0130 & $\mathrm{I}(1)$ \\
\hline FR & -3.626784 & 0.9975 & -3.632900 & 0.0001 & $\mathrm{I}(1)$ \\
\hline
\end{tabular}

Source: Authors`Computation (2020)

$* * * 1 \%$ level 
The econometric analysis of time series data requires a test of stationarity property of such data in order to avoid a spurious empirical finding. Against this backdrop, the standard Augmented Dickey-Fuller (ADF) and Phillips-Perron (PP) tests were utilized in investigating behavior of the data employed in this study. Consequently, the outcomes of the tests as shown in table two (2) indicate that only economic growth data are stationary at level while other variables are stationary after first differencing. This implies that the study utilized a combination of I (1) and I (0) data for its empirical analysis, this consequently motivated estimation of Bounds test and ARDL model Bounds Test (Pesaran and Pesaran, 1997; Pesaran, Shin and Smith, 2001).

Table 3: ARDL Bounds Test

Null Hypothesis: No long-run relationships exist

\begin{tabular}{lll}
\hline \hline Test Statistic & Value & $\mathrm{k}$ \\
\hline \hline F-statistic & 2.522004 & 4 \\
\hline \hline Critical Value Bounds & \\
\hline \hline Significance & I0 Bound & I1 Bound \\
\hline \hline $5 \%$ & 2.86 & 4.01 \\
\hline \hline
\end{tabular}

\section{Source: Authors`Computation (2020)}

This study made use of the Bounds Test in examining the long run relationship between external debt and economic growth in Nigeria. It could be submitted that external debt and economic growth did not have a long run relationship because from the table, the value of F-Statistic is less than the upper and lower Critical Value Bounds at 5\% level of significance. Therefore, the Null hypothesis of no long run relationship could not be rejected in the table. This implies that cointegrating relationship does not exist between external debt and economic growth in the country. This motivated estimation of short run relationship between the studied variables in the study. 
Table 4: The Relationship External Debt and Economic Growth in Nigeria

Dependent Variable: EC

Method: ARDL

\begin{tabular}{|l|l|l|l|}
\hline Short Run & Coefficient & T-statistics & Probability \\
\hline EC(-1) & $-0.611914 * *$ & 2.817204 & 0.0226 \\
\hline ExtD & $-4.0 \mathrm{E}+147^{* *}$ & 2.448278 & 0.0346 \\
\hline DSP & $1.2 \mathrm{E}+145^{*}$ & 1.820742 & 0.1061 \\
\hline Exch & $-1.2 \mathrm{E}+149^{*}$ & 1.857539 & 0.1003 \\
\hline FR & $5.9 \mathrm{E}+144^{* * *}$ & 4.121464 & 0.0033 \\
\hline R-Squared & 0.77 & & \\
\hline DW & 2.699954 & \\
\hline
\end{tabular}

Source: Authors`Computation (2020) *Significant at 10\%, **Significant at 5\%, ***Significant at $1 \%$

The above table shows estimated results of external debt and economic growth nexus in Nigeria. It is instructive to state that external debt and debt service payment did not have the expected sign. Meanwhile, the R-Squared of the estimated model indicates that all independent variables explained about $77 \%$ of the systematic variations in the dependent variable, economic growth while $23 \%$ was left unaccounted for as a result of a random chance. The lagged value of economic growth shows that past economic growth has a significant negative relationship with the present economic growth in Nigeria.

Similarly, external debt and economic growth have a negative relationship. This relationship is significant at 5\% level of significance. A unit change in eternal debt reduces economic growth by $4 \%$ in the country.

This finding is supported by the submission of Udeh, Ugwu and Onwuka (2016), Ogege and Ekpudu (2010) in a similar studies in Nigeria. While it contradicts the finding of Sulaiman and Azeez (2012) in a related study in country. However, debt servicing and economic growth have a positive relationship. The relationship is significant at $10 \%$ level of significance. A unit change in debt servicing leads to an increase in economic growth by $1.2 \%$. This finding contradicts the argument of Udeh, Ugwu and Onwuka (2016). Similarly, exchange rate and economic growth have an inverse relationship which is significant at $10 \%$ level of significant. A unit change in exchange rate brings economic growth down by $1.2 \%$ in the country. Whereas, the relationship between foreign reserves and economic growth is positive significantly. A unit change in foreign reserves brings about an increment in the Nigerian economic growth by $5.9 \%$. 


\section{Conclusions}

While investigating the nexus between external debt and economic growth in Nigeria from 1981 to 2018, this study employed ARDL and Bounds Test to address its objective. The significant contributions of this study to the field of research are as follows; past economic growth did not contribute to the present economic growth in Nigeria. In the same vein, external debt caused a significant setback to economic growth in Nigeria. Meanwhile, debt servicing and economic growth had a direct relationship in the country. Exchange rate contributed a negative impact on economic growth. Whereas, the foreign reserves contributed a positive significant impact on economic growth in Nigeria,

Consequently, the emergence of these crucial findings make this study to recommend the following for the policy makers in Nigeria in particular, and other highly indebted countries in Africa that past external debts in Nigeria are inhibitors to economic growth in the country. Therefore, policymakers in Nigeria should explore other means of financing country`s deficit budget rather than external debt.

\section{References:}

1. Adepeju, A. A., Salau, A. S. and Obayelu, A. E. (2007). "The effects of External Debt Management on Sustainable Economic Growth and Development: Lessons from Nigeria", Munich Personal Respective (MPRA) Paper No.2147.

2. Adesola, W.A. (2009). Debt Servicing and Economic Growth in Nigeria: An Empirical Investigation, Global Journal of Social Sciences, 8(2); $\quad 1-11$.

3. Alam, N. and Taib, F. (2013). An Investigation of the Relationship of External Public Debt with Budget Deficit, Current Account Deficit and Exchange Rate Depreciation in Debt Trap and Non-DebtTrap Countries. European Scientific Journal, 9 (22); 23-31.

4. Bamidele, T. B. \& Joseph, A. I (2013). Financial Crisis and External Debt Management in Nigeria, International Journal of Business and Behavioural Sciences, 3(4): 16- 24

5. Central Bank of Nigeria. (2018). Statistical bulletin. Abuja: Central Bank of Nigeria

6. Dickey, D.A., and Fuller, W.A. (1979). Distribution of the Estimators for Autoregressive Time Series with a Unit Root. Journal of the American Statistical Association, 74: 427-431

7. Ijeoma, N.B. (2013). An Empirical Analysis of the Impact of Debt on the Nigerian Economy. International Journal of Arts and Humanities, 2 (7); 165-19 
8. Kasidi, F. \& Said, A. M. (2013). Impact of External Debt on Economic Growth: A Case Study of Tanzania, Advances in Management and Applied Economics, 3(4): 59 - 82.

9. Malik, S., Hayat, M.K. \& Hayat, M.U (2010). External Debt and Economic Growth: Empirical Evidence from Pakistan",International Research Journal of Finance and Economics, 44: 88-97

10. Ogbonna G. and Appah E. (2016) External Debt Management and Economic Growth in Nigeria.1981 - 2013: International Journal of African and Asian Studies, 13; 76-84

11. Ogege, S. and Ekpudu, J.E. (2010). The Effect of Debt Burden on the Nigerian Economy. Journal of Research in National Development, 8 (2); 13- 21

12. Ogunmuyiwa, M.S. (2011). Does External Debt Promote Economic Growth? Current Research Journal of Economic Theory 3(1); 29 35.

13. Pesaran, M. H., Shin, Y., and Smith, R. J. (2001). Bounds testing approaches to the analysis of level relationships. Journal of Applied Econometrics, 16; 289-326.

14. Pesaran, M. and Pesaran, B. (1997). Microfit 4.0 (windows version). New York: Oxford University Press Inc.

15. Phillips, P. C. and Perron, P. (1988). Testing for a unit root in time series regression. Biometrika, 75: 335-346.

16. Sanusi, J.O. (2003). Management of Nigeria's Domestic Debt. Key Note Address by the Governor of the Central Bank of Nigeria at the $7^{\text {th }}$ Monetary Policy Forum organized By the Central Bank of Nigeria at the CBN Conference Hall, Abuja.

17. Siddique, A., Selvanathan,E.A. \& Selvanathan, S. (2015). The Impact of External Debt on Economic Growth: Empirical Evidence from Highly Indebted Poor Countries. Discussion Paper 15.10. University of Western Australia Department of Economics

18. Sulaiman, L.A. and Azeez, B.A. (2013). Effect of External Debt on Economic Growth of Nigeria. Journal of Economics and Sustainable Development, 3(8); 71-79

19. Udeh, S. N., Ugwu, J. I. and Onwuka, I. O. (2016). External Debt and Economic Growth: The Nigeria Experience. European Journal of Accounting Auditing and Finance Research, 4(2); 33-48:

20. World Bank, (2019). World Development Indicators. Washington D.C. onlineathttp://data.worldbank.org/data-catalog/worlddevelopmentindicators. 